\title{
Studies on Human Thyroxine-Binding Globulin (TBG)
}

\author{
I. PURIFICATION OF TBG AND IMMUNOLOGIC STUDIES \\ ON THE RELATIONSHIP BETWEEN TBG FROM NORMAL \\ PERSONS AND THOSE WITH TBG “DEFICIENCY”
}

\author{
James S. Marshall and Jack Pensky \\ From the Departments of Medicine and Pathology, Case Western Reserve \\ University School of Medicine, Cleveland, Ohio 44106
}

\begin{abstract}
A B S T R A C T A method for obtaining highly purified thyroxine-binding globulin (TBG) from whole human serum is presented. The method employs relatively simple procedures of step-wise ammonium sulfate precipitation followed by column chromatography on DEAE cellulose and DEAE Sephadex. The final product produces a single protein band on disc electrophoresis. The sedimentation constant of the TBG thus purified is 3.91 and its calculated mol wt is 54,000 . An antiserum to the highly purified TBG produced a single arc on immunoelectrophoresis. When the antiserum was reacted against normal human serum or against serum from subjects deficient in TBG, each produced two arcs-one identical with that produced by the antigen alone. The second arc is probably the result of a contaminating protein in the antigen, present in too low a concentration to be detectable by disc gel electrophoresis. It is concluded that some persons with TBG "deficiency" have a circulating protein, immunologically indistinguishable from $T B G$, which is defective in its ability to bind thyroxine.
\end{abstract}

\section{INTRODUCTION}

It has been estimated (1-4) that $99.95 \%$ of circulating thyroxine in normal human serum is bound to the three carrier proteins, thyroxine-binding globulin (TBG), albumin, and thyroxine-binding prealbumin (TBPA). Of these, TBG is present in trace amounts, estimated to be $1-2 \mathrm{mg} / 100 \mathrm{ml}$ (5), but nevertheless it binds about $40 \%$ of the circulating thyroxine in vitro (6) in normal human serum. More recent studies indicate that TBG may bind a considerably greater percentage of circu-

This work was presented in part at the 41 st Annual Meeting of The Central Society for Clinical Research, Chicago, Ill., November 1968.

Received for publication 26 August 1968 and in revised form 14 November 1968. lating thyroxine in vivo (7). Since TBG thus acts as an important reservoir for circulating thyroid hormone, further characterization of its physical and chemical properties might provide insight into its physiologic function.

TBG has recently been obtained in a highly purified state by Giorgio and Tabachnick (8), who utilized column electrophoresis, ammonium sulfate fractionation, gel filtration, and preparative disc electrophoresis. They reported values for the sedimentation constant, the molecular weight, and the amino acid content of TBG.

The literature contains several reports of families of persons with TBG "deficiency." These have been identified by either the combination of an abnormally low serum protein-bound iodine concentration and an abnormally high resin sponge uptake of radiotriiodothyronine or by electrophoretic demonstration of absence of radioactivity in the $\alpha$-globulin region after addition of ${ }^{131} \mathrm{I}$ thyroxine to their serum. Genetic studies of some of these families indicated that the "deficiency" of TBG is transmitted as an X-linked dominant characteristic (9, 10).

The purpose of this paper is to present (a) a relatively simple method for separating TBG from human serum in a highly purified state, and $(b)$ evidence that in hereditary TBG "deficiency" a protein immunologically indistinguishable from TBG is present which is unable to bind thyroxine.

\section{METHODS}

\section{Materials}

Dowex $2-\times 10$ was obtained in the prewashed form (AG2- $\times 10$ ) from BioRad Laboratories, Richmond, Calif. It was prepared for column chromatography as previously described (11).

Diethylaminoethyl (DEAE) cellulose, Whatman DE 52, was obtained from H. Reeve Angel, Inc., Clifton, N. J. 
DEAE Sephadex A-50 was obtained from Pharmacia Fine Chemicals, Piscataway, N. J.

Radioactive thyroxine $\left(\mathrm{T}_{4^{-}}{ }^{131} \mathrm{I}\right)$ was obtained from Abbott Laboratories, North Chicago, Ill. Radioactive thyroxine $\left(\mathrm{T}_{4}{ }^{-25} \mathrm{I}\right)$ was obtained from Mallinckrodt Nuclear Corp., St. Louis, Mo.

Human blood was obtained by venipuncture and allowed to clot overnight at $4^{\circ} \mathrm{C}$. Sera were separated by centrifugation, pooled, and stored at $-60^{\circ} \mathrm{C}$ before use. Serum from TBG-"deficient" persons was obtained from affected members of the family previously reported (9).

\section{Methods}

Purification of TBG. All operations were done at $4^{\circ} \mathrm{C}$ in a cold room, except where noted. Human serum, usually $2000-3000 \mathrm{ml}$, was adjusted to approximately $40 \%$ saturation with powdered ammonium sulfate, sedimented at $36,000 \mathrm{~g}$ for $1 \mathrm{hr}$, and the supernatant solution dialyzed exhaustively against distilled water according to conditions previously described (12). This $40 \%$ supernatant solution was percolated at room temperature through a column of Dowex $2-\times 10$ anion exchange resin, $15 \times 110 \mathrm{~cm}$, equilibrated with $0.06 \mathrm{~m}$ Tris-chloride ${ }^{1}$ buffer, $\mathrm{pH}$ 7.3. The main band of unadsorbed protein emerging at the void volume of the column contained TBG as determined by cellulose acetate electrophoresis by a method previously reported from this laboratory (13), and was saved for further processing. The protein content of this fraction was adjusted to 10-12 OD units $/ \mathrm{ml}$ at $280 \mathrm{~m} \mu$ by dilution with $0.06 \mathrm{M}$ Tris-chloride buffer, $\mathrm{pH}$ 7.3. Powdered ammonium sulfate was added with constant stirring to $60 \%$ saturation ( $390 \mathrm{~g} / \mathrm{liter}$ ) and the solution allowed to stand for $48 \mathrm{hr}$. At this time the undissolved protein formed a floating zone which was difficult to centrifuge; accordingly, it was filtered through fluted filter paper (No. 12 Whatman filter paper). The clear yellow filtrate was brought to $65 \%$ saturation by addition of $34 \mathrm{~g}$ ammonium sulfate/liter and the resulting suspension was allowed to settle over a period of $48-72 \mathrm{hr}$. Most of the clear supernatant was carefully decanted, and the remaining concentrated suspension of $65 \%$ precipitate was sedimented for $1 \mathrm{hr}$ at $36,000 \mathrm{~g}$. The sedimented precipitate was redissolved in a minimal volume of cold distilled water and dialyzed against $10-20$ volumes of $0.06 \mathrm{M}$ Tris-chloride buffer, $\mathrm{pH} 7.3$, with two changes of buffer $24 \mathrm{hr}$ apart. This fraction, labeled "dialyzed $65 \%$ ppt," was the starting material for chromatography on DEAE cellulose. $\mathrm{T}_{4^{-}}{ }^{125} \mathrm{I}$ was added in tracer amounts to this fraction to facilitate location of TBG in subsequent purification steps.

\section{DEAE cellulose column chromatography}

DEAE cellulose was prepared for equilibration according to the manufacturer's recommendations and equilibrated with $0.06 \mathrm{~m}$ Tris-chloride buffer, $\mathrm{pH} 7.3$. A $50 \%$ (v/v) slurry of cellulose and buffer was packed into a $2.5-\mathrm{cm}$ diameter glass column at a buffer flow rate of $70 \mathrm{ml} \mathrm{hr}^{-1} \mathrm{~cm}^{-2}$ to a height of $40 \mathrm{~cm}$. The volume of dialyzed $65 \%$ precipitate applied to the column ranged between 35 and $50 \mathrm{ml}$, representing material derived from $400-500 \mathrm{ml}$ of serum. Elution was carried out at a constant flow rate of $150 \mathrm{ml} / \mathrm{hr}$, first with equilibration buffer until all the unadsorbed protein was washed from the column and finally with a linear concentration gradient of sodium chloride. The gradient limit was 2 liters of $0.15 \mathrm{M} \mathrm{NaCl}$ dissolved in equilibration buffer; the mixing vessel contained 2 liters of equilibration buffer

\footnotetext{
${ }^{1}$ Trishydroxymethylaminomethane.
}

stirred magnetically. Fractions of $10-20 \mathrm{ml}$ were collected volumetrically in plastic counting tubes. The radioactivity of all tube contents was determined in a well-type scintillation counter. Contents of tubes comprising the peak of radioactivity were pooled, concentrated by pressure dialysis to about $5 \mathrm{ml}$, and dialyzed for $24-48 \mathrm{hr}$ against 1 liter of 0.06 м Tris-chloride buffer, $\mathrm{pH}, 8.6$, with two changes of buffer.

\section{DEAE Sephadex column chromatography}

DEAE Sephadex A50 was prepared according to the manufacturer's instructions and was equilibrated with $0.06 \mathrm{M}$ Tris-chloride buffer, $\mathrm{pH}$ 8.6. A stirred $20 \%$ (v/v) slurry of DEAE Sephadex in equilibrating buffer was packed by gravity flow into a $0.9-\mathrm{cm}$ diameter column to a height of $25 \mathrm{~cm}$. The dialyzed sample from the DEAE cellulose column was applied and elution carried out with a linear concentration gradient of sodium chloride (limit $=0.2 \mathrm{M}$ ), as described before. The volume in each gradient reservoir was $500 \mathrm{ml}$. Elution was carried out under gravity flow at a rate of $10-20 \mathrm{ml} / \mathrm{hr}$. Fractions of $5-\mathrm{ml}$ were collected in glass counting tubes. All tubes were counted for radioactivity and the OD at $280 \mathrm{~m} \mu$ was determined for each fraction. Those fractions comprising the ascending side of the radioactive peak were pooled and concentrated at a final volume of 1-2 $\mathrm{ml}$ by pressure dialysis.

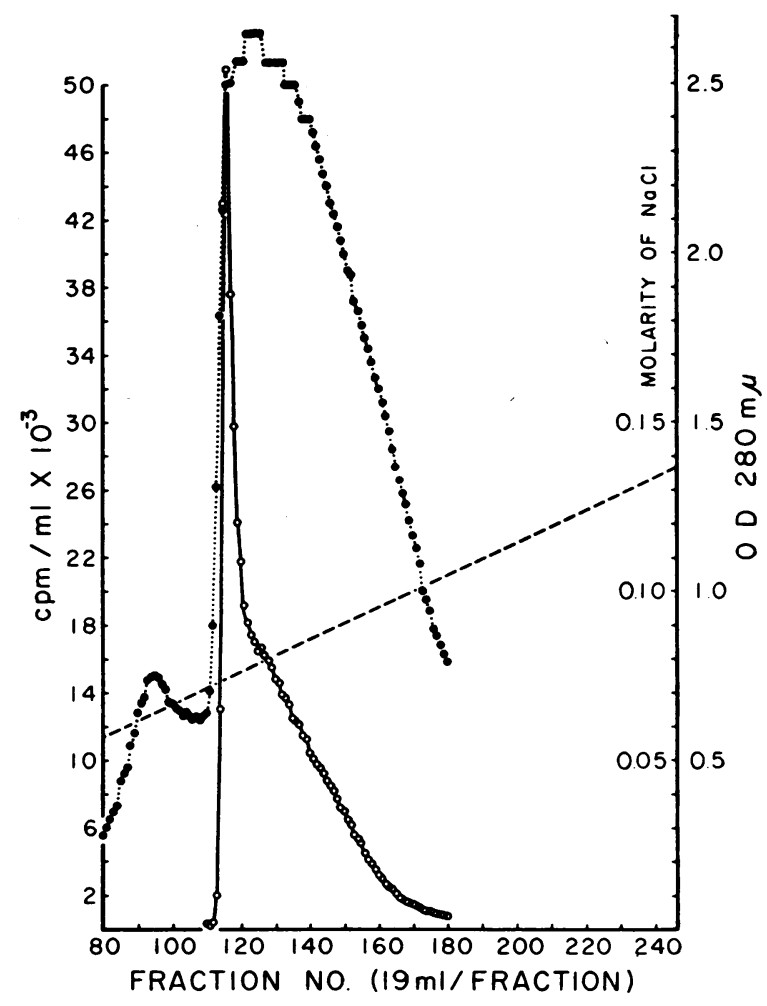

FIGURE 1 Portion of chromatogram showing gradient elution of TBG from DEAE cellulose. Column dimensions, $2.5 \times 40 \mathrm{~cm}$; sample volume, $35 \mathrm{ml}$. Thyroxine- ${ }^{125} \mathrm{I}\left(\mathrm{T}_{4^{-125}} \mathrm{I}\right)$ radioactivity, $\mathrm{O}-\mathrm{O}$; optical density at $280 \mathrm{~m} \mu, \bullet \cdots \bullet$; molarity of sodium chloride, - - - The gradient was started at tube 40 . Other conditions as in text.

Purification and Immunologic Studies of TBG 


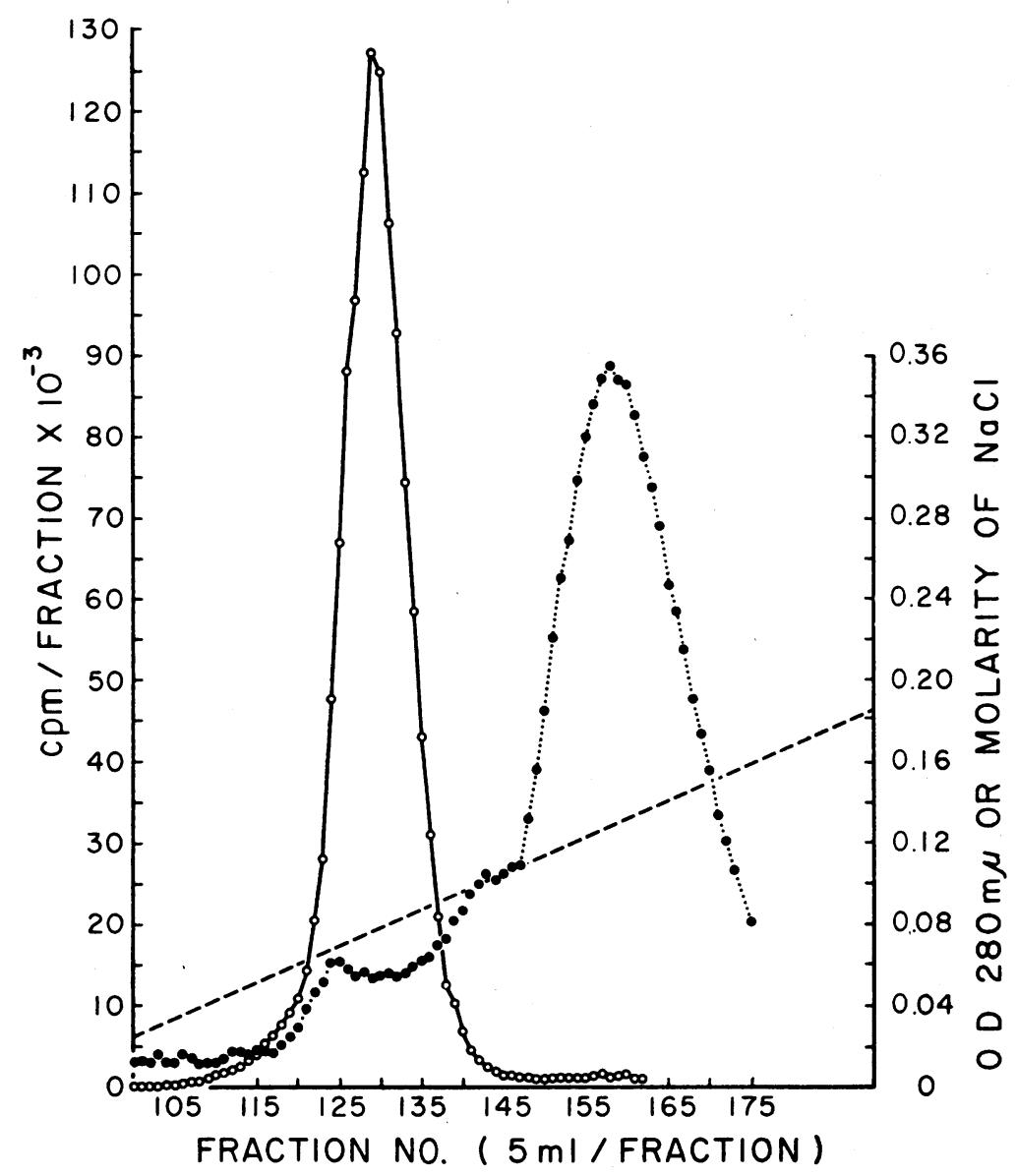

FIGURE 2 Portion of chromatogram showing gradient elution of TBG from DEAE Sephadex. Column dimensions, $0.9 \times 25 \mathrm{~cm}$; sample volume $4.0 \mathrm{ml}$. $\mathrm{T}_{4^{-125}} \mathrm{I}$ radioactivity, $\mathrm{O}-\mathrm{O}$; optical density at $280 \mathrm{~m} \mu, \bullet \cdots \bullet$; molarity of sodium chloride, ---. The gradient was started at tube 17.

\section{Cellulose acetate electrophoresis}

Cellulose acetate electrophoreis was initially carried out in a Buchler electrophoresis cell by a method previously described (13). Later electrophoreses were carried out in a Beckman Microzone cell. The buffer used in the Beckman cell was 0.25 м Tris acetate, $\mathrm{pH} 8.9$ (13). After electrophoresis, the cellulose acetate membrane was dried in an oven for $20 \mathrm{~min}$ at $90^{\circ} \mathrm{C}$. Identification of the presence of TBG in each of the purification steps was done by radioautography, which was carried out as previously described (13).

\section{Disc gel electrophoresis}

Analytical disc gel electrophoresis was carried out by the method of Davis (14), using Tris glycine buffer, $\mathrm{pH}$ 8.2-8.4.

\section{Immunoelectrophoresis}

Immunoelectrophoresis was carried out by the method of Scheidegger (15), using electrode and gel buffers of veronalcalcium lactate as described by Hirschfeld (16). Radioautography of precipitin lines was accomplished by adding

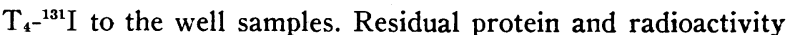
were removed by washing with $1 \% \mathrm{NaCl}$. After drying, slides were exposed to X-ray film for a period of approxi. mately 2 wk.

\section{Antibody preparation}

New Zealand albino rabbits weighing about $2.5 \mathrm{~kg}$ were immunized with highly purified TBG eluted from the DEAE Sephadex column. The initial injection was made intravenously in Freund's complete adjuvant followed by a second and third subcutaneous injection of antigen alone at 4-day intervals. A fourth dose of antigen was injected subcutaneously 10 days after the third injection. 5 days after the last injection, bleeding was carried out. All injections contained about $0.5 \mathrm{mg}$ of antigen protein.

\section{Ultracentrifugal analysis}

Sedimentation constants in sucrose density gradients were determined by ultracentrifugation, as described by Martin and Ames (17). After centrifugation the contents of the tube were fractionated into 40 samples of 10 drops each in counting tubes. The radioactivity of each sample was counted 


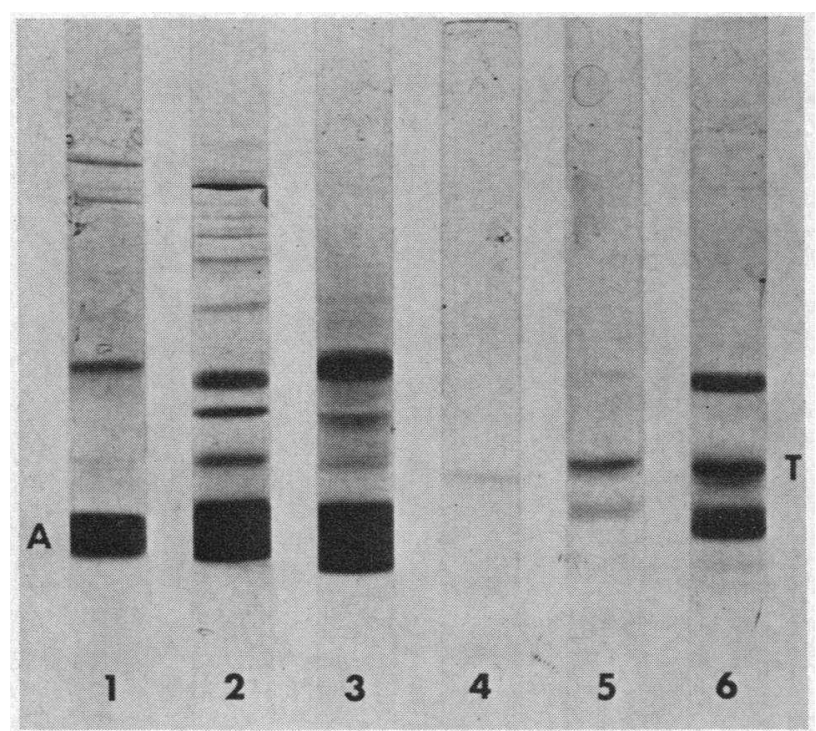

Figlre 3 Analytical disc gel electrophoresis of successive steps in TBG purification. 1, unconcentrated fraction unadsorbed by Dowex $2-\times 10$ column; 2, dialyzed $65 \%$ ammonium sulfate precipitate; 3 , radioactivity peak from DEAE cellulose column, shown in Fig. 1; 4, tubes 120-125 DEAE Sephadex, Fig. 2; 5, tubes 127-132, DEAE Sephadex, Fig. 2; 6, tubes 133-137, DEAE Sephadex Fig. 2. Samples 2-6 were concentrated about 20 -fold. Direction of migration was toward the bottom. $A=$ albumin; $T=\mathrm{TBG}$.

and then the sample was diluted with $3 \mathrm{ml}$ distilled water and the OD at $210 \mathrm{~m} \mu$ determined (18).

\section{Protein content}

Protein content of serum fractions was determined by measuring absorption in $1-\mathrm{cm}$ cells at $280 \mathrm{~m} \mu$ in a Zeiss PMQII spectrophotometer or by the method of Lowry, Rosebrough, Farr, and Randall (19). In some cases the absorption at $210 \mathrm{~m} \mu$ of proteip solutions was determined (18).

\section{RESULTS}

Purification of TBG. Chromatography of dialyzed 65\% precipitate on DEAE cellulose, as depicted in Fig. 1 , typically resulted in a biphasic peak of bound $T_{4}{ }^{125} \mathrm{I}$ in which the first, sharper portion emerging contained TBG and the second was attributable to albumin. The contents of fractions in the first $\frac{1}{2}-\frac{2}{3}$ of the TBG peak were pooled and concentrated for further chromatography on DEAE Sephadex. A typical chromatogram of material recovered from a DEAE cellulose column and applied to a DEAE Sephadex column is shown in Fig. 2. It was possible to remove all contaminating albumin and all but a trace of other contaminating proteins by this procedure. The purest TBG was invariably contained in the earliest (first one-third) of the radioactive peak emerging from the DEAE Sephadex column. Fig. 3 shows disc gel electrophoretograms of proteins from several steps in the purification and the purest TBG obtained from DEAE Sephadex chromatography. The final material appeared homogeneous by disc gel electrophoresis. The electrophoretic mobility of purified TBG and its ability to bind $T_{4}{ }^{131} I$ were confirmed by radioautography of samples labeled with $\mathrm{T}_{4}{ }^{131} \mathrm{I}$ after electrophoresis on cellulose acetate. The absence of $\mathrm{T}_{4-}{ }^{131} \mathrm{I}$-binding in persons with TBG "deficiency" was also confirmed. A photograph of these radioautographs is shown in Fig. 4.

It was not possible to calculate exactly the yield or degree of purification of TBG resulting from the procedures employed because of contamination of all but the final fraction by albumin-bound radioiodinated thyroxine and losses associated with selection of fractions with the highest purity. However, on the basis of protein recovered in the final fraction, assuming the TBG content to be $2 \mathrm{mg} / 100 \mathrm{ml}$ of serum (5), the final yield of TBG was approximately $10-20 \%$.

Physical characterization of $T B G$. The small amount of pure TBG available made studies on its sedimentation behavior in the analytical ultracentrifuge unfeasible; however, it was possible to obtain a value for its sedimentation constant by ultracentrifugation of radiothyroxine-labeled TBG in a sucrose density gradient by the method of Martin and Ames (17). The results of such a centrifugation are shown in Fig. 5. The calculated $\mathrm{S}_{20, \infty}$ of TBG in this experiment was 3.91, using purified human serum albumin as a marker protein and taking the value for its sedimentation constant as 4.6 (20). The value obtained corresponds very closely to that found by Giorgio and Tabachnick (3.92) for their purified TBG in the analytical ultracentrifuge (8). The mol wt estimated from the sedimentation constant (21) was

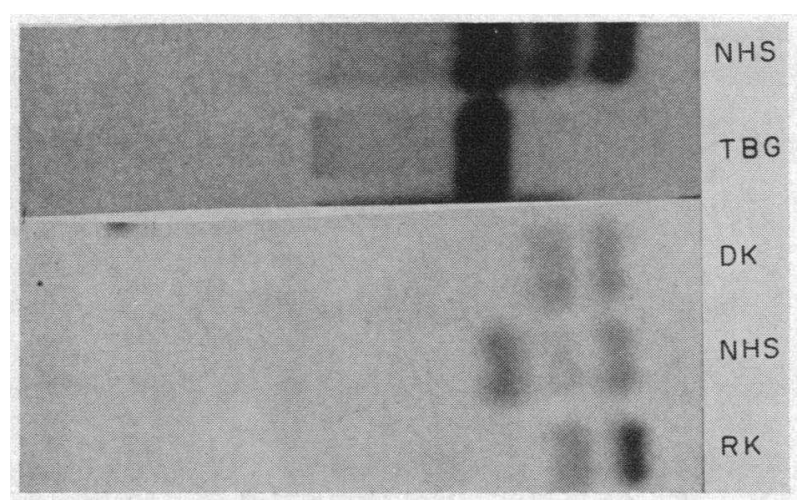

Figure 4 Radioautographs of cellulose acetate electrophoretograms. All samples enriched with $T_{4}-^{131} I$. Direction of migration was to the right. NHS = normal human serum, TBG = highly purified thyroxine-binding globulin, RK and DK = two affected brothers from a family with TBG "deficiency." The top two samples and bottom three samples were run separately under similar conditions.

Purification and Immunologic Studies of TBG 


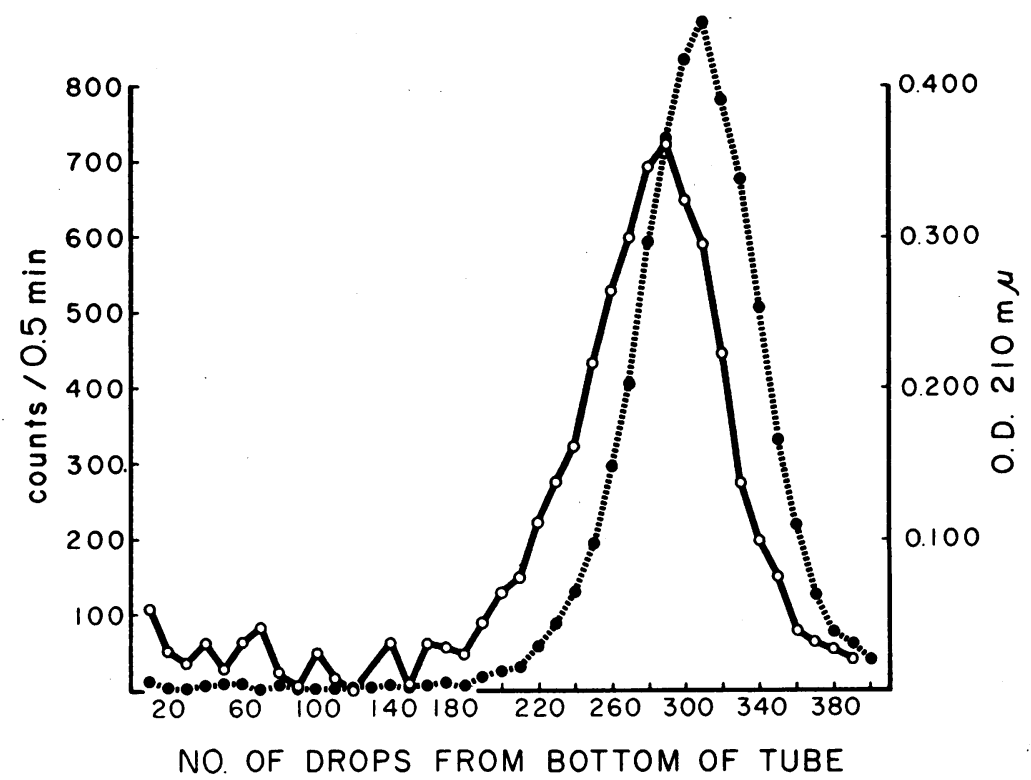

FIGURE 5 Density gradient ultracentrifugation of TBG. The tube contained $30 \mu \mathrm{g}$ of $\mathrm{T}_{4^{-1}}{ }^{125} \mathrm{I}$ TBG and $500 \mu \mathrm{g}$ of purified human serum albumin in a volume of $0.15 \mathrm{ml}$. Centrifugation for $17 \mathrm{hr}$ at $35,000 \mathrm{rpm}$ in a $5-20 \%$ linear sucrose gradient at $2^{\circ} \mathrm{C}$. Radioactivity per 10-drop sample, $---\bullet$; optical density at $210 \mathrm{~m} \mu$ of same sample after dilution with water to $3 \mathrm{ml}$, $\mathrm{O}$ O. The calculated $s_{20 \text {, w }}$ was 3.91 .

54,000 , in fair agreement with the figure of 58,000 obtained by Giorgio and Tabachnick.

Immunological characterization. Immunodiffusion experiments, using the most highly purified TBG as anti- gen and rabbit antiserum to TBG (see Methods), showed that the rabbit antiserum formed two precipitin lines with normal human serum and a single line with the TBG antigen. Furthermore, under these conditions,

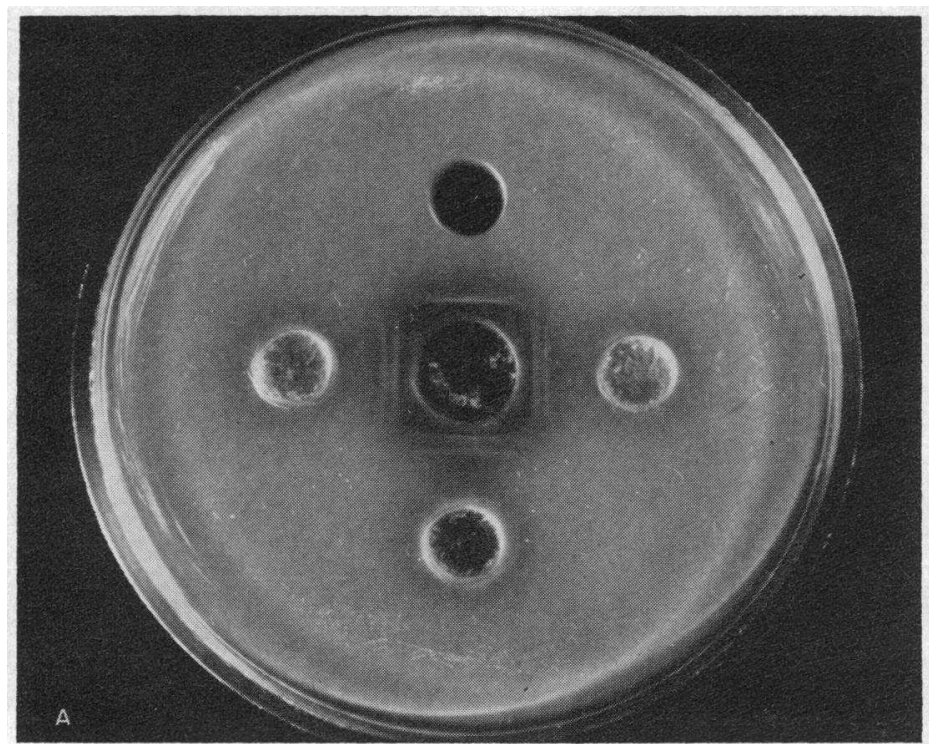

FigURE $6 \mathrm{~A}$ Double diffusion in agarose. Top well contained purified TBG; each side well contained serum from a person "deficient" in TBG; the bottom well contained normal human serum, and the center well was filled with rabbit antiserum to TBG. 


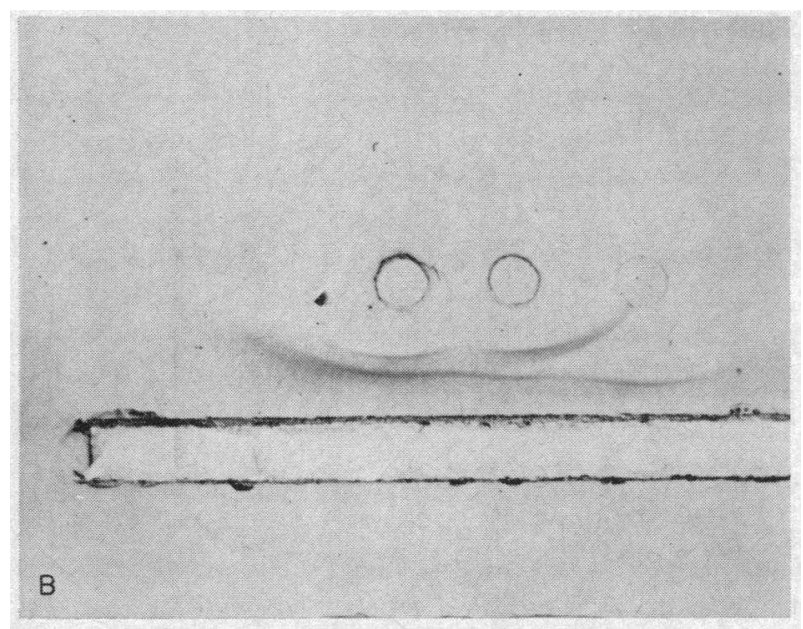

Figure $6 \mathrm{~B}$ Double diffusion in agarose. Left well contained TBG "deficient" serum, center well contained normal human serum, and the right well contained purified TBG. Rabbit antiserum to TBG in bottom trench. Diffusion for $24 \mathrm{hr}$ at room temperature.

serum from individuals, shown to have no thyroxinebinding protein in the TBG position by radioautography, produced two precipitin lines that formed a pattern of complete antigenic identity with those of normal serum. A photograph of a double diffusion experiment showing these results is given in Fig. $6 \mathrm{~A}$ and $\mathrm{B}$.

Similar findings were made when purified TBG, normal human serum, and TBG-"deficient" serum were compared in immunoelectrophoresis, using rabbit antiTBG in the antiserum trench. A photograph of immunoelectrophoresis slides showing these results is given in Fig. $7 \mathrm{~A}$. It is clear from the foregoing experiments that rabbit antiserum to highly purified TBG contains antibody which reacts with TBG and one other protein in serum and that the same proteins in normal and TBG-"deficient" serum react, i.e., TBG in normal and "deficient" serum are immunologically indistinguishable.

Radioautography of immunoelectrophoresis experiments described above was carried out by adding $\mathrm{T}_{4}{ }^{131} \mathrm{I}$ to the contents of the wells (Fig. 7 B). A single arc of radioactivity was seen when both normal human serum and the highly purified TBG antigen were reacted against rabbit antiserum to TBG. This radioactive arc corresponded to the arc in the stained preparations. When immunoelectrophoretic radioautography was carried out with TBG-"deficient" serum reacted against the antiserum, no arc of radioactivity appeared.

The physical properties and the immunologic characteristics of the protein we have isolated indicate its close correspondence to the most highly purified TBG isolated by Giorgio and Tabachnick (8). In this regard we have confirmed their finding that, in a mixture of TBG and albumin, TBG emerges before albumin from a
Sephadex G100 column, leading to an erroneously high value for its molecular weight. The method we have presented offers the advantage of relative simplicity in the purification of TBG directly from human serum.

\section{DISCUSSION}

Our interest in the prevalence of TBG "deficiency" in large populations has required a convenient assay for TBG. The availability of highly purified TBG and a specific antibody to it should facilitate the development of an immunoassay for this protein.

Antiserum to highly purified TBG when reacted against the antigen produces a single precipitin line, but when reacted against normal human serum or serum from TBG-"deficient" persons produces a second line. The presence of this second precipitin line indicates that

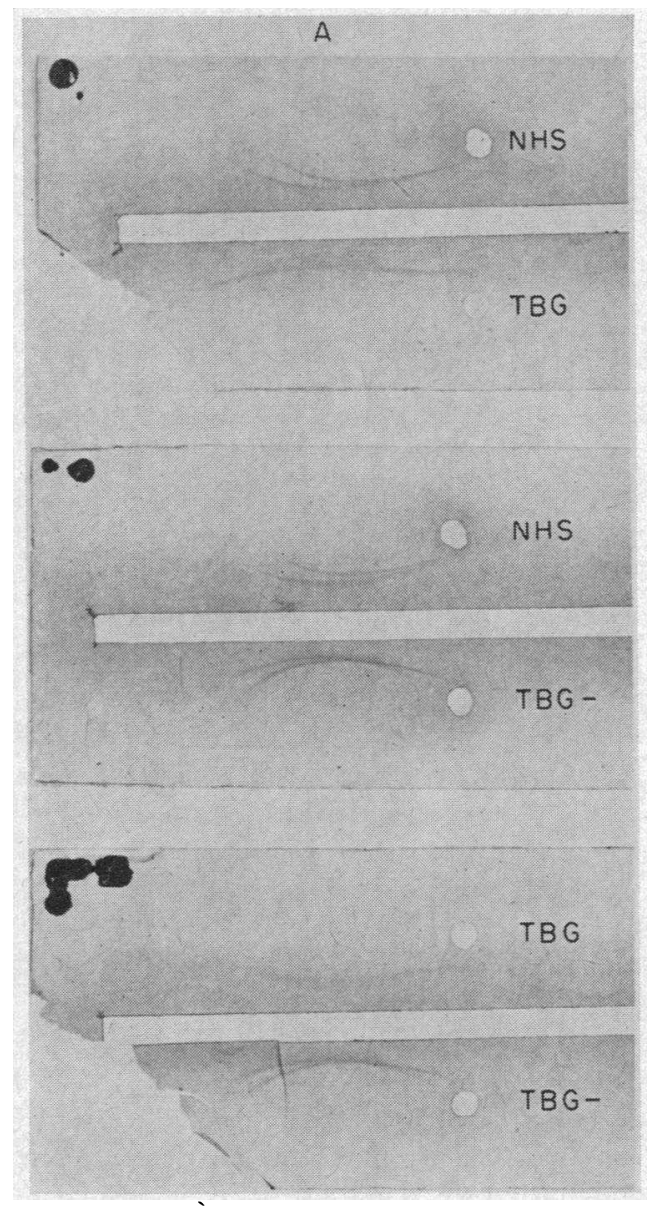

FIGURE $7 \mathrm{~A}$ Immunoelectrophoresis of highly purified thyroxine-binding globulin (TBG), normal human serum (NHS), and TBG-"deficient" serum (TBG") against rabbit antiserum to TBG. The well contents are as labeled; troughs contained rabbit antiserum to TBG in all cases. Anode is to the left. 


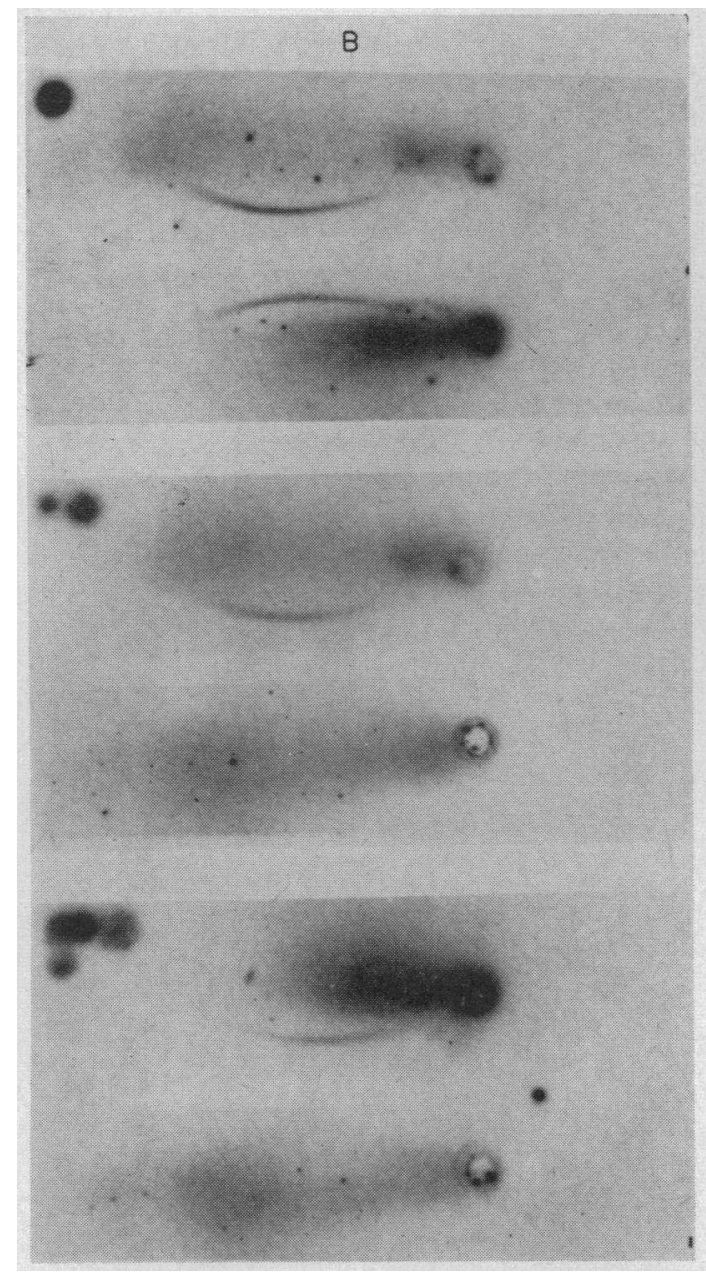

Figure $7 \mathrm{~B}$ Radioautographs of slides in Fig. $7 \mathrm{~A} . \mathrm{T}_{4^{-}}{ }^{181} \mathrm{I}$ added to well samples which are the same as in Fig. $7 \mathrm{~A}$.

the highly purified TBG used for immunization probably contains a contaminating protein in such small concentration as to be undetectable by analytic disc gel electrophoresis at the concentration employed. Since the second precipitin line is not associated with radioactivity when $\mathrm{T}_{4}{ }^{131} \mathrm{I}$ is present, it does not possess thyroxinebinding ability (Fig. 7 B).

Binding capacities for the highly purified TBG for thyroxine have not been determined in view of the probability that our purest product is not homogenous. At the present stage of purification of TBG, maximum binding of thyroxine could be influenced either by nonhomogeneity of the protein or by denaturation. The relative importance of these factors could not be assessed at this point. Giorgio and Tabachnick (8) have encountered this dilemma, since their highly purified TBG demonstrates only $25 \%$ of the expected binding capacity for thyroxine, assuming one binding site/molecule of protein. While they have stressed denaturation of their protein as the probable cause for this finding, their data do not exclude nonhomogeneity of their final product as an alternative cause.

The highly purified antigen, normal human serum, and TBG-"deficient" serum all react to TBG antiserum with a line of identity indicating that persons with TBG "deficiency" have in their serum a protein immunologically indistinguishable from TBG in normal serum. The abnormality in TBG "deficiency" appears to reside in this inability of the defective protein to bind thyroxine. Preliminary immunodiffusion experiments, using serially diluted normal human serum and TBG-"deficient" serum, indicate that the amount of immunoreactive TBG in the two serums is approximately the same. Although these findings are true for the two affected members of the family previously reported (9) and presumably true for the other affected members of this family, the generalization that this occurs in all persons with TBG "deficiency" should not be made.

Thus, TBG from individuals with TBG "deficiency" is a serum protein bearing a genetically controlled biochemical defect that does not affect its antigenicity. These data support the view that the antigenic and thyroxine-binding sites on the TBG molecule are different. Another example of such a protein is the nonfunctional variant of $C^{\prime} 1$ esterase inhibitor (22) found in some cases of hereditary angioneurotic edema.

The availability of highly purified TBG will permit studies on the characteristics of the binding site for thyroxine. Such studies are now in progress.

\section{ACKNOWLEDGMENTS}

Dr. Pensky was the recipient of a research career development award from the U. S. Public Health Service, the National Institutes of Health, Bethesda, Md. This work was supported in part by grants AM 11462 and AI 06349 from the National Institutes of Health.

\section{REFERENCES}

1. Ingbar, S. H., L. E. Braverman, N. A. Dawber, and G. Y. Lee. 1965. A new method for measuring the free thyroid hormone in human serum and an analysis of the factors that influence its concentration. J. Clin. Inv'est. 44: 1679.

2. Sterling, K., and M. A. Brenner. 1966. Free thyroxine in human serum: simplified measurement with the aid of magnesium precipitation. J. Clin. Inv'est. 45: 153.

3. Robbins, J., and J. E. Rall. 1957. The interaction of thyroid hormones and protein in biological fluids. Recent Progr. Hormone Res. 13: 161.

4. Oppenheimer, J. H., R. Squef, M. I. Surks, and H. Hauer. 1963. Binding of thyroxine by serum proteins evaluated by equilibrium dialysis and electrophoretic techniques. Alterations in nonthyroidal illness. J. Clin. Invest. 42: 1769.

5. Tata, J. R. 1961. Purification of thyroxine-binding globulin and thiyroxine-binding pre-albumin. Clin. Chim. Acta. 6: 819. 
6. Ingbar, S. H., and N. Freinkel. 1960. Regulation of thyroid hormone metabolism. Recent Progr. Hormone Res. 16: 353 .

7. Woeber, K. A., and S. H. Ingbar. 1968. The contribution of thyroxine-binding prealbumin to the binding of thyroxine in human serum, as assessed by immunoadsorption. J. Clin. Invest. 47: 1710.

8. Giorgio, N. A., and . M. Tabachnick. 1968. Thyroxine protein interactions. V. Isolation and characterization of a thyroxine-binding globulin from human plasma. J. Biol. Chem. 243: 2247.

9. Marshall, J. S., R. P. Levy, and A. G. Steinberg. 1966. Human thyroxine-binding globulin deficiency. N. Engl. J. Med. 274: 1469.

10. Nikolai, T. F., and U. S. Seal. 1967. X-chromosomelinked inheritance of thyroxine-binding globulin deficiency. J. Clin. Endocrinol. Metab. $27: 1515$.

11. Boman, H. G., and L. E. Westlund. 1956. Protein chromatography on an anion-exchange resin. Arch. Biochem. Biophys. 64 : 217.

12. Pensky, J., L. R. Levy, and I. H. Lepow. 1961. Partial purification of a serum inhibitor of C'1-esterase. J. Biol. Chem. 236: 1674.

13. Marshall, J. S., and L. S. Tompkins. 1968. Effect of $o, p^{\prime} D D D$ and similar compounds on thyroxine-binding globulin. J. Clin. Endocrinol. Metab. 28: 386.
14. Davis, B. J. 1964. Disc electrophoresis. II. Method and application to human serum proteins. Ann. N.Y. Acad. Sci. 121: 404.

15. Scheidegger, J. J. 1955. Une micro-methode de l'immuno-électrophorese. Int. Arch. Allergy Appl. Immunol. $7: 103$.

16. Hirschfeld, J. 1959. Individual precipitation patterns of normal rabbit sera. Acta Pathol. Microbiol. Scand. 46: 229 .

17. Martin, R. G., and B. N. Ames. 1961. A method for determining the sedimentation behavior of enzymes: application to protein mixtures. J. Biol. Chem. 236: 1372 .

18. Tombs, M. P., K. B. Cooke, F. Sauter, and N. F. McLagan, 1960. Protides of the Biological Fluids. Elsevier Publishing Co., New York.

19. Lowry, O. H., J. J. Rosebrough, L. Farr, and R. J. Randall. 1951. Protein measurement with the folin phenol reagent. J. Biol. Chem. 193: 265.

20. Cohn, E. J., W. L. Hughes, Jr., and J. H. Weare. 1947. Preparation and properties of serum and plasma proteins. XIII. Crystalization of serum albumins from ethanolwater mixtures. J. Amer. Chem. Soc. 69: 1753.

21. Schachman, H. K. 1959. Ultracentrifugation In Biochemistry. Academic Press, Inc., New York.

22. Rosen, F. S., P. Charache, J. Pensky, and V. Donaldson. 1965. Hereditary angioneurotic edema: two genetic variants. Science. 148: 957. 